\title{
PENDEFINISIAN INSTRUMEN EVALUASI WEBSITE E-COMMERCE BUSINESS TO CONSUMER (B2C)
}

\author{
Suci Lestarini Nurhayati dan Putu Wuri Handayani
}

Fakultas Ilmu Komputer, Universitas Indonesia, Kampus Baru UI Depok, Jawa Barat, 16424, Indonesia

E-mail: suci.lestarini@gmail.com

\begin{abstract}
Abstrak
Dalam meningkatkan keunggulan kompetitif suatu organisasi, aplikasi e-commerce dapat digunakan untuk meningkatkan proses supply chain suatu organisasi. Saat ini di Indonesia sudah banyak organisasi yang mulai memanfaatkan aplikasi e-commerce B2C (Business to Consumer) dalam memasarkan produknya. Implementasi konsep B2C dilakukan melalui pembuatan website $e$ commerce yang digunakan untuk bertransaksi secara langsung dengan konsumen. Namun, pembuatan website pribadi untuk perdagangan elektronik tersebut tidak serta merta memberikan kesuksesan bagi perusahaan yang mengimplementasikannya. Di Indonesia, belum banyak website B2C yang bermunculan. Oleh karena itu, sebuah instrumen evaluasi terhadap website e-commerce perlu didefinisikan untuk meningkatkan kinerja website e-commerce. Paper ini akan membahas mengenai proses pendefinisian instrumen evaluasi sebuah website e-commerce ditinjau dari sudut pandang pengunjung pertama, intermittent, dan frequent. Hal ini dikarenakan masing-masing pengunjung memiliki karakteristik yang berbeda dan membutuhkan sebuah instrumen evaluasi yang berbeda pula. Pendefinisian instrumen evaluasi website e-commerce ini didasarkan pada beberapa teori yang sudah ada dan berbagai macam literatur lainnya.
\end{abstract}

Kata Kunci: website e-commerce, instrumen evaluasi, business to consumer

\begin{abstract}
In improving the competitive advantage of an organization, e-commerce applications can be used to improve an organization's supply chain process. Currently in Indonesia there are many organizations are beginning to utilize e-commerce B2C (Business to Consumer) applications in marketing their products. Implementation is done through development of $\mathrm{B} 2 \mathrm{C}$ e-commerce website that used to trade directly with consumers. However, development of personal websites for electronic commerce does not necessarily provide success for the company that implements it. In Indonesia, only a few B2C websites are popping up. Therefore, an evaluation instrument for e-commerce website needs to be defined to improve the performance of e-commerce website. This paper will discuss the process of defining an evaluation instrument for e-commerce website from the point of view of the first visitors, intermittent, and frequent. This is because each visitor has different characteristics and require a different evaluation instruments. Defining the evaluation instrument e-commerce website is based on several existing theories and various other literature.
\end{abstract}

Keywords: e-commerce website, evaluation instrument, business to consumer

\section{Pendahuluan}

Kemunculan internet secara umum dan World Wide Web (WWW) secara khusus telah mengakibatkan revolusi yang besar dalam aktivitas-aktivitas bisnis yang ada di dunia [1]. Teknologi informasi telah menghasilkan produkproduk baru, mengarahkan kepada pembentukan proses produksi yang baru, bentuk organisasi bisnis yang berbeda, dan peluang pasar yang berbeda. Salah satunya, internet dan teknologi informasi telah membawa bentuk baru perdagangan yang disebut dengan electronic commerce atau e-commerce.
Kalangan bisnis memilih untuk menerapkan konsep e-commerce di dalam organisasinya dengan tujuan meminimalkan pengeluaran, meningkatkan efisiensi, dan memberikan jaminan pelayanan yang lebih baik kepada konsumen dan pihak-pihak yang turut bekerja sama, seperti pemasok. Saat ini, e-commerce telah dianggap menjadi komponen yang semakin penting dalam organisasi bisnis secara umum untuk mendapatkan keunggulan dalam berkompetisi dan mendapatkan akses terhadap pasar global yang luas [2].

Salah satu bentuk e-commerce adalah Business to Consumer $(B 2 C)$. B2C adalah $e$ - 
commerce di mana para pelaku bisnis melakukan transaksi jual beli produk maupun jasa secara langsung kepada konsumen tanpa melalui perantara, seperti distributor dan agen. Konsep B2C menawarkan banyak kelebihan baik bagi pelaku bisnis maupun bagi konsumen, seperti kemudahan dalam melakukan transaksi karena pelaku bisnis dan konsumen tidak perlu berada pada tempat dan waktu yang sama. Oleh karena itu, banyak pelaku bisnis yang tertarik untuk menerapkan konsep $\mathrm{B} 2 \mathrm{C}$ dalam e-commerce. Pada akhirnya, bukanlah suatu hal yang mengherankan apabila nilai pemasukan dunia dari penerapan konsep $\mathrm{B} 2 \mathrm{C}$ pada e-commerce meningkat dari tahun ke tahun. Berdasarkan laporan dari eMarketer (May 2001), pemasukan dunia dari B2C berkisar antara 53 hingga 238 triliun dolar dan pada tahun 2004 meningkat menjadi 428 hingga 2134 juta dolar.

Di Indonesia, banyak usaha B2C yang memanfaatkan internet dan teknologi informasi dalam pemasaran produknya, seperti toko buku Gramedia, toko busana muslim Rabbani, dan lainlain. Implementasi konsep B2C biasanya melalui pembuatan website e-commerce yang digunakan untuk bertransaksi secara langsung dengan konsumen. Website e-commerce membuat jangkauan pasar sebuah usaha menjadi lebih global. Website e-commerce pun telah menjadi sesuatu yang sangat penting bagi banyak industri, khususnya Usaha Kecil Menengah (UKM) dalam berinteraksi dengan stakeholder dan konsumen [3].

Namun, pembuatan website-website $e$ commerce tersebut tidak serta merta memberikan kesuksesan bagi perusahaan yang mengimplementasikannya. Di Indonesia, pada tahun 1995-1999 sebanyak 95\% website B2C mengalami kegagalan atau tidak berkembang. Sedangkan di sisi lain, perdagangan elektronik B2C sangat bergantung kepada website masingmasing yang berfungsi sebagai toko online dalam memasarkan produk dan jasa, meraih konsumen, serta melakukan transaksi jual beli. Pandangan konsumen terhadap kinerja suatu website sangat berpengaruh kepada keputusan dan perilaku konsumen dalam berbelanja.

Seiring dengan jumlah transaksi melalui website e-commerce yang semakin meningkat, desain dari website menjadi salah satu faktor penting penentu kesuksesan [4]. Berdasarkan data dari Forrester Research, diperkirakan bahwa website dengan desain yang tidak baik dapat menyebabkan menghilangnya 50\% kunjungan berulang yang potensial (potential repeat visits). Rettig dan LaGuardia (1999) menyarankan bahwa sebuah evaluasi efektif dapat menghasilkan desain yang lebih baik dan dapat memenuhi kebutuhan pengguna. Oleh karena itu, sebuah instrumen evaluasi terhadap website e-commerce perlu didefinisikan untuk meningkatkan kinerja website e-commerce. Dan tentu saja, jika dapat dikelola dengan baik, website-website tersebut akan menjadi salah satu faktor penentu kesuksesan sebuah bisnis B2C.

Paper ini membahas mengenai proses pendefinisian instrumen evaluasi sebuah website e-commerce ditinjau dari sudut pandang pengunjung pertama, intermittent, dan frequent. Hal ini dikarenakan masing-masing pengunjung memiliki karakteristik yang berbeda dan membutuhkan sebuah instrumen evaluasi yang berbeda pula. Pendefinisian instrumen evaluasi website e-commerce ini didasarkan pada beberapa teori yang sudah ada dan berbagai macam literatur lainnya.

E-commerce business to consumer (B2C) terdiri dari dua bagian yaitu bagian pertama adalah bisnis dan bagian kedua adalah konsumen [5]. Pada B2C, konsumen dapat membeli produk dan jasa dari sebuah perusahaan ataupun dapat melakukan aktivitas lainnya, seperti promosi, pemesanan, dan pembayaran secara online.

Dalam e-commerce B2C terdapat beberapa kegiatan utama yang biasa dilakukan, yaitu promosi, pemesanan, pembayaran, pengiriman produk dan layanan setelah pembelian. Promosi produk dan jasa sebuah perusahaan pada umumnya dimasukkan ke dalam iklan yang dipasang pada beberapa website terkenal. Konsumen dapat melakukan pemesanan terhadap suatu produk ataupun jasa tertentu ataupun sekedar mendapatkan informasi mengenai produk ataupun jasa yang disukainya melalui website. Konsumen melakukan pembayaran produk atau jasa yang telah dipesan melalui metode pembayaran (seperti melalui transfer ke rekening bank, pembayaran di tempat atau cash on delivery, melalui kartu kredit, atau melalui layanan escrow, seperti PayPal) yang telah dipilih sebelumnya.

Produk digital, seperti perangkat lunak dan musik dapat diunduh secara langsung melalui website setelah melakukan pembelian. Namun, pengiriman produk yang tidak digital, seperti buku, baju, alat olahraga, dan lain sebagainya, bergantung kepada perusahaan yang menyelenggarakan penjualan barang-barang tersebut.

Pada umumnya, di Indonesia pengiriman produk demikian, dilakukan melalui jasa pengiriman berbayar, seperti TIKI. Layanan konsumen setelah pembelian adalah rantai terakhir dari keseluruhan proses bisnis B2C antara perusahaan dengan konsumen. Konsumen dapat mengirimkan e-mail kepada layanan konsumen 
dan perusahaan dapat mengembangkan sebuah knowledge based system untuk membantu para konsumen dalam mencari solusi dari permasalahan mereka.

Karakteristik pengunjung website $e$ commerce. Pengunjung sebuah website dalam penelitian ini didefinisikan sebagai mereka yang pernah melakukan kunjungan ke sebuah website untuk melakukan eksplorasi dan tidak sampai melakukan transaksi. Pengunjung sebuah website dapat dikategorikan ke dalam tiga karakteristik [6], yakni pengunjung pertama (first-time customer) di mana karakteristik dari pengujung pertama antara lain adalah kebutuhannya untuk mendapatkan pemahaman awal mengenai layanan yang diberikan oleh sebuah website e-commerce, layanan yang tidak diberikan, dan pengetahuan dasar mengenai bagaimana mendapatkan layanan tersebut. Seseorang dikategorikan sebagai pengunjung pertama (first-time customer) sebuah website apabila pengunjung telah melakukan kunjungan ke sebuah website (walaupun tanpa melakukan transaksi apapun di website tersebut) sebanyak 1 - 2 kali.

Pengunjung intermittent (intermittent customer) di mana karakteristik dari pengujung intermittent antara lain adalah kebutuhannya akan sebuah struktur yang telah tersusun baik, tampilan yang familiar, dan keamanan sepanjang kegiatan eksplorasi website. Seseorang dikategorikan sebagai pengunjung intermittent apabila pengunjung (walaupun tanpa melakukan transaksi apapun di website tersebut) melakukan kunjungan ke sebuah website sebanyak 2-5 kali.

Pengunjung frequent (frequent customer) di mana pengunjung frequent sebuah website pada umumnya menghendaki adanya jalan pintas (shortcut) atau makro untuk meningkatkan kinerjanya dalam melakukan pekerjaan yang berulang, adanya informasi-informasi detil, dan layanan tambahan untuk memuaskan kebutuhan yang beragam. Seseorang dikategorikan sebagai pengunjung frequent apabila pengunjung (walaupun tanpa melakukan transaksi apapun di website tersebut) telah melakukan kunjungan ke sebuah website lebih dari lima kali.

\section{Metodologi}

Wina Witanti dan Falahah dalam sebuah makalahnya yang berjudul Kerangka Evaluasi Situs Web Perguruan Tinggi (Studi Kasus Situs Web Perguruan Tinggi di Wilayah Jawa Barat dan Banten) mengatakan bahwa secara garis besar kerangka umum evaluasi sebuah website dapat dilihat dari tiga sudut pandang, yakni dari sudut pembuat website (web developer), pengunjung website (web surfer), dan pemilik/pengelola website (web owner). Pengelompokan ini didasarkan pada kenyataan bahwa dalam pembuatan, pengelolaan, dan pengembangan website, ketiga pihak tersebut turut dilibatkan dengan peranannya masing-masing.

Pembuat website (web developer) pada umumnya akan menilai sebuah website dari sudut pandang desain dan tampilan serta dari faktor apakah sebuah website telah memenuhi standarstandar yang ditetapkan. Pemilik atau pengelola website (web owner) akan lebih memertimbangkan faktor-faktor yang berhubungan dengan pengunjung seperti statistik mengenai distribusi, interaksi, serta profil pengunjung. Sedangkan, pengunjung website (web surfer) akan lebih memerhatikan masalah konten, keakuratan informasi, aksesibilitas, fiturfitur yang ditawarkan sebuah website, dan usability.

Menurut Dimitros, David, dan Paris dalam makalahnya yang berjudul "A Proposed Template for the Evaluation of Web Design Strategies", sebuah website yang baik harus dapat menarik dan menumbuhkan kepercayaan pengunjung sehingga pengunjung mau melakukan kunjungan ulang ke website tersebut. Berdasarkan penelitian yang mendalam terhadap literatur-literatur internasional maka Dimitros, David, dan Paris menetapkan bahwa ada empat faktor yang dapat digunakan untuk menentukan kesuksesan sebuah website $e$ commerce, yakni stickiness, globalisasi dan kustomisasi, aksesibilitas dan availability, serta keamanan dan privasi.

Di internet, lebih dari jutaan website telah muncul dan lebih dari ribuan website bertambah setiap hari (D-Lib Magazine, 2003). Oleh karena itu, merupakan hal yang sangat penting untuk dapat membuat sebuah website yang dapat menarik dan menumbuhkan kepercayaan pengunjung. Keberhasilan sebuah website dalam menarik dan menumbuhkan kepercayaan pengunjung dapat dilihat dari jumlah waktu yang dihabiskan untuk melakukan kunjungan ulang ke website tersebut. Para praktisi teknologi informasi menyebutnya sebagai stickiness.

Salah satu faktor terpenting yang memengaruhi stickiness adalah Graphical User Interface (GUI). Menurut Sutcliffe (2002), sebuah user interface harus berisikan grafik dan teks yang memberikan informasi penting juga menarik para pengunjung. Sedangkan, Nielsen (1999) berpendapat bahwa konten dari sebuah website merupakan atribut yang paling penting untuk membuat pengunjung mengunjungi ulang sebuah website. Faktor-faktor tersebut dapat dipenuhi salah satunya dengan menghindari elemen-elemen website yang menganggu, seperti banner, marquee, penggunaan animasi yang berlebihan, 
ataupun hal-hal lainnya yang tidak memenuhi standar dari sebuah desain website.

Faktor penting lainnya yang mempengaruhi stickiness website adalah kualitas dari konten atau informasi yang diberikan kepada pengunjung. Konten atau informasi yang diberikan oleh sebuah website harus berasal dari sumber yang terpercaya. Selain itu, konten atau informasi tersebut harus diperbarui secara rutin untuk menghindari hal-hal tidak baik terjadi, seperti konten atau informasi yang kadaluarsa [7].

Hal penting lainnya yang mudah diimplementasikan dan penting adalah mengenai feedback dari pengunjung. Sebuah website seharusnya menyediakan fasilitas bagi pengunjung untuk dapat memberikan kritik serta sarannya mengenai website tersebut. Media yang dapat digunakan untuk memfasilitasi feedback pengunjung bermacam-macam, seperti melalui survei online, e-mail, ataupun formulir kritik dan saran. Faktor ini menjadi penting karena dapat membuat pengunjung merasa dilibatkan dalam perbaikan website di masa yang akan datang.

Hal lain yang memengaruhi kesuksesan sebuah website adalah faktor globalisasi dan kustomisasi. Makna dari globalisasi di sini adalah bagaimana sebuah website dapat menarik dan memberikan banyak manfaat bagi berbagai macam orang di berbagai daerah.

Faktor globalisasi menjadi hal penting karena karakteristik orang di suatu daerah berbeda dengan daerah lainnya. Perbedaan tradisi, agama, bahasa, dan cara berkomunikasi yang pada akhirnya menyebabkan respons yang berbeda pula terhadap sesuatu hal, misalkan dalam mengakses website.

Hal penting lainnya dari faktor globalisasi selain tradisi, agama, bahasa, serta cara komunikasi masyarakat sasaran adalah permasalahan legal framework. Informasi mengenai pajak juga aspek hukum lainnya, seperti kebijakan ekspor impor dari suatu negara perlu diberitahukan kepada pengunjung agar tidak terjadi hal yang tidak diinginkan.

Di sisi lainnya, seorang developer website juga harus memerhatikan aspek preferensi para pengunjungnya atau disebut juga dengan kustomisasi. Beberapa ahli serta profesional menyebut kustomisasi sebagai personalisasi. Contoh dari personalisasi ini antara lain adalah adanya berbagai macam pilihan pembayaran yang ditawarkan oleh sebuah website, seperti melalui kartu kredit, cash on delivery, paypal, dan lain sebagainya. Contoh lainnya dari personalisasi adalah adanya currency converter yang dapat memfasilitasi konversi antar mata uang.

Kemunculan alat-alat elektronik yang bervariasi saat ini, seperti Personal Digital
Assistants (PDAs), telepon genggam generasi baru dengan kemampuan browsing internet di dalamnya, serta Personal Computers (PCs) dan laptop yang memiliki kemampuan berbeda-beda dalam menampilkan informasi atau konten ke pengguna membuat berbagai perusahaan memikirkan faktor kompatibilitas dari website yang dibangunnya. Kompatibilitas website terhadap berbagai macam browser dan sistem operasi adalah faktor yang dipikirkan dari segi aksesibilitas website.

Hal lainnya yang dianggap penting dalam aksesibilitas adalah tentang kecepatan pembukaan halaman sebuah website. Website yang berat karena mengandung terlalu banyak grafik atau media animasi akan membuat pengunjung tidak tertarik untuk melakukan kunjungan balik. Rentang waktu antara 7 - 10 detik dalam membuka sebuah halaman website telah dianggap lama dan membuat pengguna tidak nyaman.

Selain kompatibilitas dan kecepatan, faktor penting lainnya dari aksesibilitas adalah bagaimana membuat sebuah website yang dapat diakses oleh semua orang, termasuk orang-orang dengan keterbatasan fisik (disabilities). Orangorang dengan keterbatasan fisik (disabilities) bisa jadi mengalami kesulitan ketika melakukan navigasi sebuah website yang dipenuhi dengan konten-konten grafis. Penggunaan warna yang terlalu banyak di dalam sebuah website akan menyulitkan bagi seseorang dengan keterbatasan penglihatan atau visually impaired. Untuk alasanalasan tersebut, pembuatan website versi lain yang diperuntukkan bagi orang-orang dengan keterbatasan fisik menjadi sangat disarankan.

Keamanan data dari segala serangan seperti spyware dan virus dalam bertransaksi merupakan isu teknologi yang sangat perlu diperhatikan dalam pembuatan website. Sampai saat ini, belum ada mekanisme yang benar-benar ampuh dalam menangani masalah keamanan dan privasi di dunia internet. Cara paling efektif yang dapat ditempuh adalah dengan menggunakan paket perangkat lunak yang terpercaya dalam melindungi data para pengguna dari serangan yang merugikan.

Selain itu, ada beberapa hal lainnya yang dapat dilakukan dalam menangani keamanan dan privasi data pengguna atau data transaksi lainnya dari sebuah website. Pertama, sebuah website tidak boleh mengumpulkan informasi atau data sensitif dari pengguna tanpa sepengetahuan pengguna. Apabila data sensitif pengguna diperlukan, maka pengelola website wajib memberitahukannya kepada pengguna, baik melalui perjanjian kesepakatan yang harus disetujui pengguna, atau melalui mekanisme lainnya. Kedua, terapkan proteksi pada level 
transaksi melalui implementasi security protocol seperti SSL (Secure Socket Layer), SET (Secure Electronic Transaction) pada website [8].

Untuk mendapatkan gambaran mengenai karakteristik website e-commerce di industri retail, maka dilakukan review terhadap beberapa website yang sukses di industri retail. Website yang dimasukkan ke dalam review adalah Amazon dan Dell. Berdasarkan analisis yang dilakukan oleh majalah Time mengenai 25 website e-commerce terbaik, maka Amazon dan Dell menjadi dua dari tiga website yang masuk dalam kategori Best Overall.

Hasil review dari website Amazon dan Dell mengindikasikan bahwa website-website tersebut pada umumnya memiliki fitur-fitur dasar sebuah website e-commerce yang lengkap seperti katalog produk, shopping cart, dan help serta fitur tambahan yang dapat mengakomodasi personalisasi, seperti Dell Recycling, Dell Studio Design, dan lain-lain.Menurut penulis, kedua website tersebut telah memenuhi empat faktor kesuksesan yang telah disebutkan pada sub bab sebelumnya, yakni stickiness (seperti tidak adanya penggunaan animasi yang berlebihan pada website Amazon dan Dell), globalisasi dan kustomisasi (seperti adanya pilihan penggunaan bahasa pada website Dell), aksesibilitas dan availibility (seperti adanya fitur Let Us Help You pada website Amazon dan fitur Support \& Help pada website Dell), juga keamanan serta privasi (seperti adanya fitur Privacy Notice pada website Amazon dan fitur Privacy Practice pada website Dell).

Pendefinisian instrumen evaluasi website $E$ commerce. Berdasarkan penjelasan bagian empat dapat didefinisikan sebuah instrumen yang akan digunakan untuk melakukan evaluasi terhadap website e-commerce, dengan spesifikasi pada industri retail. Pertama, penulis memberikan batasan bahwa instrumen evaluasi akan dibangun berdasarkan sudut pandang pengguna website atau dalam kerangka umum evaluasi website disebut sebagai pengunjung website (web surfer).

Kedua, penulis mengambil enam faktor yang akan digunakan sebagai dasar evaluasi website, yakni faktor stickiness, globalisasi dan kustomisasi, aksesibilitas dan availability, keamanan, privasi, dan fitur-fitur lanjutan (advanced feature, seperti fitur Make Money With Us pada Amazon dan fitur Seen It Advertised pada Dell). Oleh karena itu, instrumen evaluasi website e-commerce yang akan dibangun pun terdiri dari enam bagian yang dikombinasikan dari berbagai metode evaluasi sebelumnya untuk mendapatkan penilaian evaluasi yang menyeluruh.

Terdapat metode evaluasi sebelumnya yang hanya menilai dari sisi desain saja atau usability, functionality atau reliability tanpa memerhatikan faktor seperti keamanan dan privasi. Penulis juga memasukkan faktor-faktor penilaian dari "Research Web Design \& Usability Guidelines" yang diperkenalkan sejak tahun 2003 oleh Departemen Kesehatan dan Pelayanan Masyarakat Amerika Serikat bekerja sama dengan US General Services Administration. Selain itu, penulis membangun penilaian dari setiap faktor berdasarkan pada hal-hal yang telah dijelaskan pada bab dua. Penilaian dimaksudkan untuk melihat apakah pengguna website merasa puas atau merasa tidak puas terhadap hal-hal yang dievaluasi.

Penilaian menggunakan skala Likert. Skala Likert digunakan sebagai alat ukur karena skala ini dapat mengukur persepsi atau pendapat seseorang mengenai suatu hal. Responden diminta untuk memberikan nilai kepada sebuah pernyataan yang diajukan. Rentang nilai yang digunakan dari 1 - 5 dengan nilai $1=$ sangat tidak setuju, 2 = tidak setuju; $3=$ ragu-ragu, $4=$ setuju, dan 5 = sangat setuju.

Evaluasi faktor pertama yaitu stickiness. Fitur-fitur yang dimiliki sebuah website serta desain atau layout sebuah website menjadi hal yang dievaluasi pada bagian ini. Evaluasi mengenai faktor stickiness akan dibagi menjadi dua bagian, yakni evaluasi berdasarkan fitur-fitur yang dimiliki website dan berdasarkan layout website.

Evaluasi berdasarkan fitur utama website (tabel I) dimaksudkan untuk menilai sejauh mana fitur-fitur utama atau fitur dasar pada website mudah dilihat, digunakan, dan untuk menilai sejauh mana manfaat yang diberikan fitur tersebut dalam membantu pengguna melakukan transaksi di website. Sedangkan, evaluasi berdasarkan layout website (tabel II) dimaksudkan untuk menilai sejauh mana layout sebuah website memengaruhi pengunjung website untuk melakukan transaksi kembali pada website tersebut.

Evaluasi faktor kedua yaitu globalisasi dan kustomisasi. Evaluasi pada faktor ini bertujuan untuk menilai sejauh mana sebuah website telah mengakomodasi personalisasi pengguna. Faktorfaktor evaluasinya antara lain adalah bahasa, pilihan pembayaran, rekomendasi produk, produk yang akan keluar, dan kebijakan. Seluruh faktor evaluasi tersebut ditujukan untuk semua jenis pengguna. Website mengakomodasi penggunaan berbagai macam bahasa, khususnya penggunaan bahasa mother tounge negara asalnya dan bahasa Inggris sebagai bahasa universal.

Evaluasi faktor ketiga yaitu aksesibilitas dan availibility. Evaluasi pada faktor ini bertujuan untuk menilai sejauh mana sebuah website memiliki aksesibilitas yang baik, sejauh mana 
sebuah website dapat mengakomodasi keterbatasan pengguna (seperti pada pengguna yang tunanetra), dan sejauh mana sebuah website dapat mengakomodasi berbagai macam teknologi yang digunakan oleh pengguna (seperti penggunaan browser dan resolusi layar yang berbeda). Faktor tesebut penting ditujukan untuk keseluruhan jenis pengguna.

Evaluasi faktor keempat yaitu keamanan. Evaluasi pada faktor ini digunakan untuk menilai sejauh mana sebuah website telah memerhatikan faktor keamanan transaksi yang terjadi dalam website. Faktor-faktor evaluasinya antara lain meliputi autentikasi (misal login) dan expire time. Login seorang pengguna di dalam sistem website akan expire apabila dalam jangka paling tidak satu jam ia tidak melakukan aktivitas di website tersebut (idle).

Evaluasi faktor kelima yaitu privasi. Evaluasi pada faktor ini bertujuan untuk menilai sejauh mana sebuah website telah memerhatikan faktor keamanan data personal dari seorang pengguna. Faktor evaluasi yang dilihat adalah privacy statement untuk seluruh jenis pengguna. Privacy statement digunakan sebagai halaman yang berisikan informasi bahwa perusahaan akan mengumpulkan data pribadi pengguna untuk keperluan kustomisasi melalui cookies, spyware, ataupun mekanisme lainnya.

Evaluasi faktor keenam yaitu fitur-fitur lanjutan (advanced features). Faktor-faktor yang menjadi penilaian antara lain adalah fitur yang mendukung kegiatan komunitas sebagai media komunikasi, fitur sharing informasi produk, product deals, wish list, dan afiliasi. Fitur-fitur tersebut biasanya digunakan oleh jenis pengguna intermittent dan frequent. Fitur wish list berfungsi untuk melakukan pencatatan terhadap produkproduk yang tidak ada di website namun diinginkan oleh pengguna. Fitur afiliasi memfasilitasi pengguna untuk mendapatkan keuntungan dengan menjualkan produk website tersebut kepada pihak lain melalui mekanisme tertentu.

\section{Hasil dan Pembahasan}

Dalam melihat apakah kerangka evaluasi website e-commerce yang telah dibangun sebelumnya dapat dikatakan sebagai sebuah perangkat evaluasi yang baik maka penulis membuat sebuah survei. Survei berisikan pertanyaan-pertanyaan seperti yang telah tercantum pada kerangka evaluasi website $e$ commerce. Responden diminta untuk mengisi survei tersebut dengan obyek survei adalah website e-commerce yang telah dikenal keunggulannya yakni website Amazon (http://amazon.com) dan website e-commerce yang dinilai kurang baik yakni website Air Mac (http://airmac.com).

Penilaian bahwa website Amazon termasuk salah satu website e-commerce yang unggul didapatkan penulis dari analisis yang dilakukan oleh majalah Time mengenai 25 website $e$ commerce terbaik. Sedangkan, penilaian bahwa website Air Mac adalah website e-commerce yang dinilai kurang baik didapatkan penulis dari website Web Practices (http://www.webpractices.com/), yakni website yang menjadi sumber rujukan untuk $e$-business, $e$ commerce, dan multi-channel marketing.

Website Air Mac merupakan website $e$ commerce yang menyediakan produk-produk seperti air compressor untuk industri, blower, juga pompa vakum untuk daerah North Texas dan Oklahoma. Di dalam website Web Practices, website Air Mac dikatakan kurang baik dikarenakan faktor-faktor seperti menu navigasi yang tidak terlalu baik juga dikarenakan layanan penjualan yang diberikannya tidak memuaskan (dalam hal ini adalah layanan customer servicenya).

Survei terhadap dua website tersebut dimaksudkan untuk melihat perangkat evaluasi website e-commerce yang telah dirancang mampu memberikan penilaian yang tepat bahwa website Amazon lebih baik daripada website Air Mac. Survei dibuat secara online dengan menggunakan website penyedia jasa pembuatan survei online. Responden dari survei adalah mahasiswa dari dua kelas pada mata kuliah e-commerce di Fakultas Ilmu Komputer Universitas Indonesia.

Dari hasil pengisian kuesioner diketahui bahwa terdapat 39 responden yang mengisi evaluasi untuk website e-commerce Air Mac sedangkan untuk website Amazon terdapat 44 responden. Penentuan responden ditentukan dengan berpegang pada prinsip sampling insidental. Sampling insidental sendiri merupakan teknik penentuan sampel berdasarkan kebetulan sehingga siapa saja yang secara kebetulan/insidental bertemu dengan peneliti maka ia dijadikan responden [9]. Teknik sampling insidental diambil salah satunya karena pertimbangan waktu yang sempit dan tenaga yang sedikit.

Tujuan survei adalah untuk mengetahui apakah perangkat evaluasi dengan komponenkomponen yang telah didefinisikan pada bagian sebelumnya merupakan sebuah perangkat yang baik untuk memberikan penilaian terhadap sebuah website e-commerce dilihat dari sudut pandang pengguna. Salah satu parameter bahwa perangkat evaluasi tersebut akurat adalah hasil akhir 
penilaian yang diberikan oleh responden dari survei mendekati fakta yang ada. Oleh karena itu, dalam melaksanakan survei, penulis meminta responden untuk membandingkan dua website. Website pertama adalah Amazon yang sudah terkenal keunggulannya.

Sedangkan, website kedua adalah Air Mac yang dipandang kurang baik oleh beberapa ahli (http://www.webpractices.com/). Web tersebut memuat beberapa website e-commerce yang dipandang cukup baik dan beberapa website $e$ commerce yang dipandang tidak terlalu baik, baik dari segi desain, fitur-fitur yang dimiliki, maupun dari segi layanan customer service yang diberikan.
Instrumen evaluasi yang dibangun terdiri atas tiga bagian yang didasarkan pada jenis pengguna, yakni bagian untuk first-time user, intermittent user, dan frequent user. Untuk pengguna yang belum pernah mengunjungi website yang akan dievaluasi atau pernah mengunjungi website tersebut sebanyak 1-2 kali maka ia digolongkan ke dalam first-time user. Untuk pengguna yang sudah pernah mengunjungi website yang akan dievaluasi sebanyak 3-5 kali maka ia digolongkan ke dalam intermittent user. Sedangkan, untuk pengguna yang sudah pernah mengunjungi website sebanyak lebih dari 5 kali maka ia digolongkan ke dalam frequent user.

TABEL I

EVALUASI BERDASARKAN FITUR UTAMA WEBSITE

\begin{tabular}{|c|c|c|c|}
\hline Fase transaksi & Fitur yang dinilai & Deskripsi & Jenis pengguna \\
\hline \multirow[t]{8}{*}{ Pencarian informasi } & $\begin{array}{l}\text { About Us (Tentang } \\
\text { Kami) }\end{array}$ & $\begin{array}{l}\text { Informasi perusahaan pengelola website } e \text { - } \\
\text { commerce }\end{array}$ & $1^{\text {st }}$ time \\
\hline & Katalog produk & $\begin{array}{l}\text { Informasi mengenai produk atau jasa yang } \\
\text { ditawarkan }\end{array}$ & $1^{\text {st }}$ time \\
\hline & $\begin{array}{l}\text { Informasi produk } \\
\text { baru }\end{array}$ & Informasi mengenai produk atau jasa baru & Semua pengguna \\
\hline & $\begin{array}{l}\text { Frequently Asked } \\
\text { Questions } \\
\text { (FAQs) / Help }\end{array}$ & $\begin{array}{l}\text { Informasi mengenai hal yang sering ditanyakan } \\
\text { dari website tersebut }\end{array}$ & $1^{\text {st }}$ time, intermittent \\
\hline & Archive (Arsip) & Informasi mengenai konten-konten sebelumnya & $1^{\text {st }}$ time, intermittent \\
\hline & News (Berita) & Informasi mengenai berita-berita terbaru & Semua pengguna \\
\hline & Sitemap & $\begin{array}{l}\text { Memudahkan pencarian informasi struktur } \\
\text { sebuah website }\end{array}$ & $1^{\text {st }}$ time, intermittent \\
\hline & Pencarian & $\begin{array}{l}\text { Pencarian produk, penulis, manufacturer, } \\
\text { artikel terkait produk, dsb }\end{array}$ & Semua pengguna \\
\hline Pencarian informasi & Chat & $\begin{array}{l}\text { Media komunikasi antara customer service } \\
\text { dengan } \\
\text { pengguna }\end{array}$ & $1^{\text {st }}$ time, intermittent \\
\hline $\begin{array}{l}\text { Evaluasi, } \\
\text { negosiasi, } \\
\text { seleksi }\end{array}$ & Review produk & $\begin{array}{l}\text { Deskripsi umum kepada pengguna mengenai } \\
\text { kelemahan \& kelebihan suatu } \\
\text { produk/jasa }\end{array}$ & Intermitten, frequent \\
\hline \multirow{2}{*}{$\begin{array}{l}\text { Purchase, payment, } \\
\text { delivery }\end{array}$} & Shopping cart & Menyimpan produk-produk yang akan dibeli & Semua Pengguna \\
\hline & Account (Akun) & $\begin{array}{l}\text { Menyimpan data pribadi pengguna, mulai dari } \\
\text { e-mail, password, alamat rumah, kontak, dan } \\
\text { sejarah pemesanan produk/jasa }\end{array}$ & Semua Pengguna \\
\hline $\begin{array}{l}\text { Layanan } \\
\text { afterpurchase } \\
\& \text { evaluasi }\end{array}$ & Feedback & $\begin{array}{l}\text { Memungkinkan pengguna memberikan kritik } \\
\text { dan sarannya terhadap sebuah website }\end{array}$ & $1^{\text {st }}$ time, intermittent \\
\hline
\end{tabular}


TABEL II

EVALUASI BERDASARKAN LAYOUT WEBSITE

\begin{tabular}{|c|c|}
\hline Faktor yang dinilai & Jenis pengguna \\
\hline Link & $1^{\text {st }}$ time, intermittent \\
\hline Homepage/Home & $1^{s t}$ time \\
\hline Layout halaman (Page layout) & Semua pengguna \\
\hline Navigasi & $1^{\text {st }}$ time, intermittent \\
\hline Scrolling \& paging & Semua Pengguna \\
\hline Heading, judul, dan label & $1^{\text {st }}$ time, intermittent \\
\hline Tampilan teks & $1^{\text {st }}$ time, intermittent \\
\hline Widget & $1^{\text {st }}$ time \\
\hline Grafik, gambar, dan multimedia & $1^{\text {st }}$ time, intermittent \\
\hline
\end{tabular}

Setiap jenis pengguna memiliki beberapa pertanyaan yang berbeda dengan pengguna lainnya. Pertanyaan-pertanyaan tersebut disesuaikan dengan karakteristik dari masingmasing jenis pengguna. Untuk hal-hal yang akan disurvei, rancangannya telah ditetapkan pada bab sebelumnya.

Secara umum, hasil survei dari website Amazon dan Air Mac dapat direkap pada tabel III. Hasil survei direkap berdasarkan jenis pengguna. Pada tabel website Amazon terdapat enam kolom dengan dua kolom pertama, dengan nomor $2-23$ (kolom nomor pertanyaan dan nilai rata-rata dari masing-masing pertanyaan) diperuntukkan bagi first time user, dua kolom kedua dengan nomor 24- 47 untuk intermittent user, dan dua kolom berikutnya dengan nomor $48-68$ diperuntukkan bagi frequent user. Pada tabel website Air Mac hanya terdapat empat kolom, di mana dua kolom pertama diperuntukkan bagi first-time user dan dua kolom berikutnya diperuntukkan bagi intermittent user. Kolom frequent user pada website Air Mac tidak ada dikarenakan responden dari website Air Mac tidak ada yang memenuhi kriteria tersebut.

Tabel III menjelaskan bahwa rata-rata penilaian yang diberikan kepada website Amazon lebih tinggi daripada website Air Mac, baik dari segi first-time, intermittent, maupun frequent user. Rata-rata penilaian yang diberikan oleh first-time user pada website Amazon dalam rentang 1 - 5 adalah 3.76. Penilaian rata-rata dari intermittent user adalah 4.03 dan dari frequent user adalah 4.13. Di sisi lain, penilaian rata-rata yang diberikan oleh first-time user kepada website Air Mac adalah 3.25 dan penilaian yang diberikan oleh intermittent user adalah 3.93. Untuk website Air Mac, tidak terdapat penilaian dari frequent user karena tidak ada responden yang termasuk dalam kelompok frequent user dari website Air Mac. 
TABEL III

HASIL SURVEI WEBSITE AMAZON DAN AIR MAC

\begin{tabular}{|c|c|c|c|c|c|c|c|c|c|}
\hline \multicolumn{6}{|c|}{ Amazon } & \multicolumn{4}{|c|}{ Air Mac } \\
\hline No. & Nilai & No. & Nilai & No. & Nilai & No. & Nilai & No. & Nilai \\
\hline 2 & 3.8 & 24 & 4.1 & 48 & 4.3 & 2 & 3.2 & 24 & 3.4 \\
\hline 3 & 3.8 & 25 & 4 & 49 & 4.2 & 3 & 3.1 & 25 & 3.5 \\
\hline 4 & 4 & 26 & 4.1 & 50 & 4.7 & 4 & 3.2 & 26 & 3.5 \\
\hline 5 & 3.9 & 27 & 4.17 & 51 & 4.5 & 5 & 3.3 & 27 & 4 \\
\hline 6 & 3.9 & 28 & 4 & 52 & 3.8 & 6 & 2.9 & 28 & 4 \\
\hline 7 & 3.8 & 29 & 3.9 & 53 & 3.8 & 7 & 3.4 & 29 & 4 \\
\hline 8 & 3.9 & 30 & 4.2 & 54 & 4 & 8 & 3.6 & 30 & 3.8 \\
\hline 9 & 3.9 & 31 & 4.1 & 55 & 4 & 9 & 3.6 & 31 & 4 \\
\hline 10 & 3.9 & 32 & 4 & 56 & 3 & 10 & 3.4 & 32 & 3.8 \\
\hline 11 & 3.8 & 33 & 4 & 57 & 4.5 & 11 & 3.3 & 33 & 4 \\
\hline 12 & 3.95 & 34 & 4.25 & 58 & 4.5 & 12 & 3.41 & 34 & 4 \\
\hline 13 & 3.7 & 35 & 4 & 59 & 5 & 13 & 3.65 & 35 & 4.5 \\
\hline 14 & 3.51 & 36 & 3.75 & 60 & 4.5 & 14 & 2.76 & 36 & 4 \\
\hline 15 & 3.73 & 37 & 4 & 61 & 3.5 & 15 & 3.24 & 37 & 4.5 \\
\hline 16 & 3.97 & 38 & 4.5 & 62 & 3.8 & 16 & 3.14 & 38 & 4.5 \\
\hline 17 & 3.78 & 39 & 3.75 & 63 & 3.5 & 17 & 3.03 & 39 & 4 \\
\hline 18 & 3.68 & 40 & 4 & 64 & 4.5 & 18 & 3.11 & 40 & 4 \\
\hline 19 & 3.89 & 41 & 3.25 & 65 & 3.5 & 19 & 3.59 & 41 & 4.5 \\
\hline 20 & 3.72 & 42 & 4.25 & 66 & 4.3 & 20 & 3.2 & 42 & 4.5 \\
\hline 21 & 3.92 & 43 & 4.5 & 67 & 4.1 & 21 & 3.38 & 43 & 4.5 \\
\hline 22 & 3.46 & 44 & 3.75 & 68 & 4.7 & 22 & 3 & 44 & 3.5 \\
\hline \multirow[t]{3}{*}{23} & 3.69 & 45 & 4 & & & 23 & 3 & 45 & 3.3 \\
\hline & & 46 & 4.2 & & & & & 46 & 3.1 \\
\hline & & 47 & 3.9 & & & & & 47 & 3.5 \\
\hline
\end{tabular}

\section{Kesimpulan}

Berdasarkan penelitian yang telah dilakukan, survei online serta analisis data, dapat diambil kesimpulan bahwa instrumen evaluasi website $e$ commerce yang baik dapat melakukan penilaian dari segala macam sudut (layout, globalisasi dan kustomisasi, privasi dan keamanan, fitur-fitur utama, fitur-fitur tambahan, serta aksesibilitas dan availibility) dan memertimbangkan karakteristik penggunanya (first-time, intermittent ataupun frequent user). Instrumen evaluasi website $e$ commerce juga sebaiknya disegmentasikan berdasarkan tahapan-tahapan yang biasa terjadi dalam transaksi e-commerce (identifikasi kebutuhan, purchase, payment, delivery, 
pencarian informasi, dan lain-lain). Hal ini bertujuan untuk mengidentifikasi tahapan dalam proses transaksi $e$-commerce yang perlu diperbaiki lebih lanjut.

Masing-masing pengguna, yakni first-time, intermittent, dan frequent user memiliki karakteristik, pengetahuan, serta pengalaman tersendiri mengenai proses transaksi dalam website e-commerce sehingga pendefinisian kategori evaluasi hendaknya disesuaikan untuk masing-masing pengguna. Penelitian yang dilakukan oleh penulis memiliki beberapa keterbatasan, antara lain dalam hal jumlah responden yang tidak merata. Hal ini disebabkan beberapa kelemahan pada instrumen, seperti pertanyaan yang diajukan untuk masing-masing pengguna cukup banyak dan panjang, beberapa pertanyaan yang diajukan kurang jelas dan deskriptif, pertanyaan yang diajukan untuk tiga jenis pengguna tidak dibedakan halamannya sehingga memungkinkan beberapa pengguna melakukan kesalahan dalam pengisian survei.

\section{Referensi}

[1] W. Abell \& L. Lim, Business Use of the Internet in New Zealand: An Exploratory Study, Lincoln University, Canterbury, New Zealand,

http://ausweb.scu.edu.au/aw96/business/abel 1/paper.htm, 1996, retrieved March 15, 2010.

[2] S. Poon \& Swatman, "The Internet for Small Businesses: An Enabling Infrastructure for Competitiveness" In Proceedings of the Fifth
Internet Society Conference, pp. 221-31, 1995.

[3] R. Merwe \& Bekker, "A Framework and Methodology for Evaluating E-commerce Web Sites," Internet Research: Electronic Networking Applications and Policy, vol. 13, pp. 330-341, 2003.

[4] S.E. Kim, T. Shaw, \& S. Helmut, "Web Site Design Benchmarking within Industry Groups," Internet Research, vol. 13, pp. 17-26, 2003.

[5] A. Chaudhury \& J. Kuilboer, E-Business and E-commerce Infrastructure, International ed., McGraw-Hill, New York, 2001.

[6] B. Shneiderman, Designing the User Interface: Strategies for Effective HumanComputer Interaction: Second Edition, Addison-Wesley, Reading, MA, 1992.

[7] P. Katerattanakul \& K. Siau, "Measuring Information Quality of Web Sites: Development of an Instrument" ICIS '99 In Proceedings of the 20th international conference on Information Systems, pp. 279285, 1999.

[8] D. Xanthidis \& D. Nicholas, “An Investigation of the Employment (Or Not) of Web Log Analysis by Online Businesses in Greece. Centre for the Information Behaviour and the Evaluation Research" IADIS International Conference $e$ Commerce, pp.122-128, 2007.

[9] Sugiyono, Metode Penelitian Bisnis, Alfabeta, Bandung, 2008. 